\title{
Analisis Kestabilan Model Matematika Penyebaran Penyakit Schistosomiasis dengan Saturated Incidence Rate
}

\author{
Elda Widya $^{1, *}$, Miswanto $^{1}$ \& Cicik Alfiniyah ${ }^{1}$ \\ ${ }^{1}$ Departemen Matematika, Fakultas Sains dan Teknologi, Universitas Airlangga, Indonesia
}

*Corresponding author : elda.widya.indriah-2016@fst.unair.ac.id

\begin{abstract}
Schistosomiasis is a disease caused by infections of the genus Schistosoma. Schistosomiasis can be transmitted through schistosoma worms that contact human skin. Schistosomiasis is a disease that continues to increase in spread. Saturated incidence rates pay attention to the ability to infect a disease that is limited by an increase in the infected population. This thesis formulates and analyzes a mathematical model of the distribution of schistosomiasis with a saturated incidence rate. Based on the analysis of the model, two equilibrium points are obtained, namely non-endemic equilibrium points $\left(\mathrm{E}_{0}\right)$ and endemic equilibrium points $\left(\mathrm{E}_{1}\right)$. Both equilibrium points are conditional asymptotically stable. The nonendemic equilibrium point will be asymptotically stable if $r_{\mathrm{h}}>d_{\mathrm{h}}, r_{\mathrm{s}}>d_{\mathrm{s}}$ and $R_{0}<1$, while the endemic equilibrium point will be asymptotically stable if $R_{0}>1$. Sensitivity analysis shows that there are parameters that affect the spread of the disease. Based on numerical simulation results show that when $R_{0}<1$, the number of infected human populations $\left(H_{\mathrm{i}}\right)$, the number of infected snail populations $\left(S_{\mathrm{i}}\right)$, the amount of cercaria density $(C)$ and the amount of miracidia density $(M)$ will tend to decrease until finally extinct. Otherwise at the time $R_{0}>1$, the number of the four populations tends to increase before finally being in a constant state.
\end{abstract}

Keywords: kestabilan, model matematika, schistosomiasis, saturated incidence rate.

\section{Pendahuluan}

Schistosomiasis adalah penyakit yang disebabkan oleh infeksi cacing dari genus Schistosoma. Seseorang dapat terinfeksi ketika larva cacing masuk lewat kulit manusia setelah kontak dengan air yang terinfeksi schistosomiasis [1]. Schistosomiasis banyak ditemukan di daerah tropis dan subtropis. Sebagian besar daerah endemik terletak di Timur Tengah, Amerika Selatan, Asia Tenggara dan Afrika. Lebih dari 779 juta orang di dunia berisiko terinfeksi schistosomiasis [2].

Penularan schistosomiasis terjadi ketika penderita schistosomiasis buang air besar sembarangan, maka telur schistosoma akan menetas dalam air. Telur yang menetas menjadi miracidia dan masuk ke dalam tubuh siput yang dijadikan sebagai inangnya. Di dalam tubuh siput, larva tersebut berkembang menjadi cercaria lalu dikelurkan dalam air. Ketika manusia melakukan kontak dengan air yang terinfeksi schistosomiasis maka 
cercaria menembus kulit manusia. Di dalam tubuh, cercaria berkembang biak hingga menghasilkan telur. Beberapa telur dikeluarkan dari tubuh dalam tinja atau urin [3]. Jadi, telur tersebut akan melanjutkan siklus hidup schistosomiasis hingga akhirnya masuk ke tubuh manusia.

Upaya pemberantasan schistosomiasis difokuskan pada upaya pengendalian secara preventif. World Health Organization (WHO) merekomendasikan obat praziquantel untuk mengobati penderita schistosomiasis. Pemberian praziquantel harus diberikan secara berkala selama beberapa tahun agar pengobatan lebih efektif. Kendala yang dialami adalah keterbatasan ketersediaan praziquantel. Selain itu, praziquantel hanya dapat membunuh cacing yang sudah dewasa di dalam tubuh [4].

Model matematika telah digunakan secara luas untuk mendeskripsikan permasalahan real, termasuk penyebaran suatu penyakit menular. Penelitian tentang penyebaran penyakit schistosomiasis telah dilakukan oleh beberapa peneliti seperti [5], [6] dan [7]. [5] telah mengkaji tentang penyebaran schistosomiasis dengan memperhatikan penyebaran Schistosoma japonica dengan pertimbangan fluktuasi tingkat air musiman Danau Poyang di Jiangxi, Cina. Selanjutnya [6] melakukan penelitian tentang penyebaran penyakit schistosomiasis dengan adanya waktu inkubasi. Berikutnya [7] melakukan penelitian tentang penyebaran penyakit schistosomiasis dengan memperhatikan waktu tunda.

Model matematika penyebaran penyakit schistosomiasis pada manusia merujuk pada model yang digunakan oleh [7]. Model tersebut telah dilakukan modifikasi tanpa menggunakan waktu tunda. Penulis juga Merubah bentuk incidence rate yang semula bilinear incidence rate menjadi saturated incidence rate. Berdasarkan uraian di atas penulis tertarik untuk melakukan analisis titik setimbang serta melakukan interpetasi hasil simulasi numerik pada model penyebaran penyakit schistosomiasis pada manusia.

\section{Model Matematika Penyebaran Penyakit Schistosomiasis dengan Saturated Incidence Rate}

Pada bagian ini akan dijelaskan mengenai model matematika penyebaran penyakit schistosomiasis dengan saturated incidence rate yang mengacu pada jurnal yang ditulis oleh [7] berupa sistem persamaan diferensial biasa non linier yang terbagi menjadi enam kompartemen yang terbentuk dari jenis populasi manusia, populasi siput, dan populasi cacing. Populasi manusia terbagi menjadi dua subpopulasi yaitu populasi manusia rentan $\left(H_{s}\right)$ dan populasi manusia terinfeksi $\left(H_{i}\right)$. Populasi siput terbagi menjadi dua subpopulasi yaitu populasi siput rentan $\left(S_{S}\right)$ dan populasi siput terinfeksi $\left(S_{i}\right)$. Populasi cacing dibagi menjadi dua subpopulasi yaitu populasi Cercaria $(C)$ dan populasi Miracidia $(M)$. Asumsi yang digunakan dalam model matematika penyebaran penyakit schistosomiasis dengan saturated incidence rate sebagai berikut: 
1. Populasi manusia yang rentan bertambah karena adanya pertumbuhan dengan laju logistik.

2. Populasi siput yang rentan bertambah karena adanya pertumbuhan dengan laju logistik.

3. Penyebaran schistosomiasis terjadi karena adanya interaksi antara cercaria dengan manusia serta interaksi antara miracidia dengan siput.

4. Populasi manusia yang sembuh dari infeksi dapat menjadi rentan kembali.

5. Siput yang terinfeksi tidak akan bisa sembuh.

Tabel 1 Variabel dalam Model Penyebaran Penyakit Schistosomiasis dengan Saturated Incidence Rate

\begin{tabular}{|c|l|}
\hline Variabel & \multicolumn{1}{c|}{ Keterangan } \\
\hline$H_{S}(t)$ & Populasi manusia rentan pada saat $t$ \\
\hline$H_{i}(t)$ & Populasi manusia terinfeksipada saat $t$ \\
\hline$S_{S}(t)$ & Populasi siput rentan pada saat $t$ \\
\hline$S_{i}(t)$ & Populasi siput terinfeksi pada saat $t$ \\
\hline$C(t)$ & Kepadatan Cercaria pada saat $t$ \\
\hline$M(t)$ & Kepadatan Miracidia pada saat $t$ \\
\hline
\end{tabular}

Tabel 2 Parameter dalam Model Penyebaran Penyakit Schistosomiasis dengan Saturated

\begin{tabular}{|c|l|c|}
\hline Parameter & \multicolumn{1}{|c|}{ Keterangan } & Satuan \\
\hline$r_{h}$ & Laju kelahiran pada populasi manusia & $1 /$ satuan waktu \\
\hline$k_{1}$ & Kapasitas pendukung populasi manusia & individu \\
\hline$a_{c}$ & Laju transmisi cercaria terhadap manusia & $1 /$ (individu x satuan waktu) \\
\hline$\theta_{i s}$ & $\begin{array}{l}\text { Laju transmisi manusia terinfeksi ke } \\
\text { manusia rentan }\end{array}$ & $1 /$ satuan waktu \\
\hline$d_{h}$ & Laju kematian alami populasi manusia & $1 /$ satuan waktu \\
\hline$\beta$ & Tingkat kejenuhan & $1 /$ individu \\
\hline$r_{s}$ & Laju kelahiran pada populasi siput & $1 /$ satuan waktu \\
\hline$k_{2}$ & Kapasitas pendukung populasi siput & individu \\
\hline$b_{m}$ & Laju transmisi miracidia terhadap siput & $1 /$ (individu x satuan waktu) \\
\hline$d_{s}$ & Laju kematian alami populasi siput & $1 /$ satuan waktu \\
\hline$\gamma$ & Tingkat kejenuhan & $1 /$ individu \\
\hline$\sigma$ & $\begin{array}{l}\text { Laju produksi cercaria per siput yang } \\
\text { terinfeksi }\end{array}$ & $1 /$ satuan waktu \\
\hline$d_{c}$ & Laju kematian alami cercaria & $1 /$ satuan waktu \\
\hline$\alpha$ & Laju penetasan miracidia dari telur & $1 /$ satuan waktu \\
\hline$d_{m}$ & Laju kematian alami miracidia & $1 /$ satuan waktu \\
\hline
\end{tabular}


Notasi dan definisi dari masing-masing variabel serta parameter pada model penyebaran penyakit schistosomiasis dengan saturated incidence rate yang disajikan dalam Tabel 1 dan Tabel 2.

Selanjutnya untuk mempermudah penulisan maka notasi kompartemen $H_{S}(t), H_{i}(t), S_{S}(t), S_{i}(t), C(t)$ dan $M(t)$ berturut-turut dapat ditulis dengan $H_{s}, H_{i}, S_{S}, S_{i}, C$, dan $M$. Notasi tersebut diasumsikan sebagai jumlah populasi pada waktu $(t)$, sehingga harus memenuhi syarat $H_{s}, H_{i}, S_{s}, S_{i}, C, M \geq 0$. Sedangkan, seluruh parameter diasumsikan bernilai positif. Oleh karena itu, parameter yang digunakan dalam model penyebaran penyakit schistosomiasis dengan saturated incidence rate diasumsikan sebagai berikut:

$$
r_{h}, k_{1}, a_{c} \theta_{i s}, d_{h}, \beta, r_{s}, k_{2}, b_{m}, d_{s}, \gamma, \sigma, d_{c}, \alpha, d_{m}>0
$$

Berdasarkan asumsi-asumsi dan parameter yang telah dijelaskan diatas, maka model matematika penyebaran penyakit schistosomiasis dengan saturated incidence rate dinyatakan dalam persamaan diferensial sebagai berikut:

$\frac{d H_{S}}{d t}=r_{h} H_{s}\left(1-\frac{H_{S}}{k_{1}}\right)-\frac{a_{c} C H_{S}}{1+\beta C}+\theta_{i s} H_{i}-d_{h} H_{S}$

$\frac{d H_{i}}{d t}=\frac{a_{c} C H_{s}}{1+\beta C}-\left(\theta_{i s}+d_{h}\right) H_{i}$

$\frac{d S_{s}}{d t}=r_{s} S_{s}\left(1-\frac{S_{s}}{k_{2}}\right)-\frac{b_{m} M S_{s}}{1+\gamma M}-d_{s} S_{s}$

$\frac{d S_{i}}{d t}=\frac{b_{m} M S_{S}}{1+\gamma M}-d_{s} S_{i}$

$\frac{d C}{d t}=\sigma S_{i}-d_{c} C$

$\frac{d M}{d t}=\alpha H_{i}-d_{m} M$

Persamaan (1) mempresentasikan laju perubahan populasi manusia rentan per satuan waktu. Populasi manusia rentan bertambah karena adanya laju kelahiran pada populasi manusia dengan fungsi logistik serta manusia yang terinfeksi menjadi rentan setelah pulih. Sedangkan populasi manusia rentan berkurang karena adanya interaksi antara manusia rentan dan cercaria serta adanya kematian alami.

Persamaan (2) mempresentasikan laju perubahan populasi manusia terinfeksi per satuan waktu. Populasi manusia terinfeksi bertambah karena adanya interaksi antara manusia rentan dan cercaria. Sedangkan populasi manusia terinfeksi berkurang karena kematian alami dan manusia yang terinfeksi menjadi rentan setelah pulih. 
Persamaan (3) mempresentasikan laju perubahan populasi siput rentan per satuan waktu. Populasi siput rentan bertambah karena adanya laju kelahiran pada populasi siput dengan fungsi logistik. Sedangkan populasi siput rentan berkurang karena adanya interaksi antara siput rentan dan miracidia serta adanya kematian alami.

Persamaan (4) mempresentasikan laju perubahan populasi siput terinfeksi per satuan waktu. Populasi siput terinfeksi bertambah karena adanya interaksi antara siput rentan dan miracidia. Sedangkan populasi siput terinfeksi berkurang karena kematian alami.

Persamaan (5) mempresentasikan laju perubahan kepadatan cercaria per satuan waktu. Kepadatan cercaria bertambah karena adanya cercaria yang keluar dari siput dari ekskresi per wilayah. Sedangkan perubahan kepadatan cercaria berkurang karena kematian alami.

Persamaan (6) mempresentasikan laju perubahan kepadatan miracidia per satuan waktu. Kepadatan miracidia bertambah karena adanya penetasan telur miracidia pada setiap wilayah setelah dikeluarkan bersama tinja manusia terinfeksi. Sedangkan perubahan kepadatan miracidia berkurang karena kematian alami.

\section{Titik Setimbang Model Matematika Penyebaran Penyakit Schistosomiasis dengan Saturated Incidence Rate}

Keadaan setimbang suatu sistem merupakan suatu kondisi dimana laju perubahan populasi bernilai konstan. Model matematika penyebaran penyakit schistosomiasis dengan saturated incidence rate akan memiliki titik setimbang jika memenuhi $\frac{d H_{S}}{d t}=$ $\frac{d H_{i}}{d t}=\frac{d S_{S}}{d t}=\frac{d S_{i}}{d t}=\frac{d C}{d t}=\frac{d M}{d t}=0$. Berdasarkan persamaan tersebut, diperoleh dua titik setimbang yaitu titik setimbang non endemik dan titik setimbang endemik.

- Titik setimbang non endemik merupakan suatu kondisi dimana tidak terdapat penyebaran penyakit. Titik setimbang non endemik tersebut diperoleh pada saat tidak ada manusia dan siput yang terinfeksi dalam populasi $\left(H_{i}=S_{i}=C=M=\right.$ $0)$. Misalkan titik setimbang kepunahan dinotasikan dengan $E_{0}$, maka $E_{0}=$ $\left(H_{s}, H_{i}, S_{s}, S_{i}, C, M\right)=\left(\frac{k_{1}\left(r_{h}-d_{h}\right)}{r_{h}}, 0, \frac{k_{2}\left(r_{s}-d_{s}\right)}{r_{s}}, 0,0,0\right) . \quad E_{0} \quad$ akan eksis jika memenuhi

$$
\begin{array}{ll}
\text { i. } & r_{h}-d_{h} \\
\text { ii. } & r_{s}>d_{s}
\end{array}
$$

\section{- Basic Reproduction Number}

Selanjutnya akan ditentukan Basic Reproduction Number $\left(R_{0}\right)$ yang digunakan sebagai parameter ambang penentuan kriteria endemik peyakit pada populasi $\left(R_{0}\right)$ adalah parameter yang menyatakan rata-rata jumlah populasi baru yang terinfeksi 
penyakit menular terhadap individu yang rentan. Dalam penelitian ini, digunakan metode Next-Generation Matrix (NGM) untuk menghitung nilai $\left(R_{0}\right)$ yakni dengan membangun matriks yang mebangkitkan jumlah individu baru yang terinfeksi. Dari metode tersebut didapatkan nilai

$$
R_{0}=\sqrt[4]{\frac{\alpha}{\left(\theta_{i s}+d_{h}\right)}\left(\frac{\sigma}{d_{s}}\right)\left(\frac{a_{c} k_{1}\left(r_{h}-d_{h}\right)}{r_{h} d_{c}}\right)\left(\frac{b_{m} k_{2}\left(r_{s}-d_{s}\right)}{r_{s} d_{m}}\right)}
$$

- Titik setimbang endemik adalah kondisi saat terjadi penyebaran penyakit schistosomiasis. Diperoleh titik setimbang endemik yang dinyatakan sebagai $E_{1}=$ $\left(H_{s}{ }^{*}, H_{i}{ }^{*}, S_{S}{ }^{*}, S_{i}{ }^{*}, C^{*}, M^{*}\right)$, dengan

$$
\begin{aligned}
& H_{S}{ }^{*}=\frac{\left(\theta_{i s}+d_{h}\right) H_{i}{ }^{*}+\beta \sigma \frac{\left(\theta_{i s}+d_{h}\right)}{d_{c}} H_{i}{ }^{*} S_{i}{ }^{*}}{\frac{a_{C} \sigma}{d_{c}} S_{i}{ }^{2}} \\
& S_{S}{ }^{*}=\frac{d_{s} S_{i}{ }^{*}+\left(\frac{\alpha \gamma d_{s}}{d_{m}}\right) H_{i}{ }^{*} S_{i}{ }^{*}}{\frac{\alpha b_{m} H_{i}{ }^{*}}{d_{m}}} \\
& C^{*}=\frac{\sigma}{d_{c}} S_{i}{ }^{*} \\
& M^{*}=\frac{\alpha}{d_{m}} H_{i}{ }^{*} \\
& H_{i}{ }^{*}=\frac{a_{1} S_{i}{ }^{* 2}+a_{2} S_{i}{ }^{*}}{a_{3} S_{i}{ }^{2}+a_{4} S_{i}{ }^{*}+a_{5}}
\end{aligned}
$$

dengan

$$
\begin{aligned}
& a_{1}=k_{1} a_{c}\left(\frac{\sigma}{d_{c}}\right)^{2}\left(\left(r_{h}-d_{h}\right) \beta\left(\theta_{i s}+d_{h}\right)-d_{h} a_{c}\right) \\
& a_{2}=k_{1}\left(r_{h}-d_{h}\right)\left(\theta_{i s}+d_{h}\right) \frac{a_{c} \sigma}{d_{c}} \\
& a_{3}=r_{h}\left(\beta \sigma \frac{\left(\theta_{i s}+d_{h}\right)}{d_{c}}\right)^{2} \\
& a_{4}=2 r_{h}\left(\theta_{i s}+d_{h}\right)^{2} \frac{\beta \sigma}{d_{c}} \\
& a_{5}=r_{h}\left(\theta_{i s}+d_{h}\right)^{2}
\end{aligned}
$$


dan $S_{i}{ }^{*}$ merupakan akar positif dari persamaan

$$
c_{1} S_{i}^{* 4}+c_{2} S_{i}^{* 3}+c_{3} S_{i}^{* 2}+c_{4} S_{i}^{*}+c_{5}=0
$$

dengan

$$
\begin{aligned}
c_{1}= & a_{1}{ }^{2} b_{3}+a_{1} a_{3} b_{4}+a_{3}{ }^{2} b_{5} \\
c_{2}= & 2 a_{1} a_{2} b_{3}+\left(a_{1} a_{4}+a_{2} a_{3}\right) b_{4}+2 a_{3} a_{4} b_{5}-\left(a_{1}^{2} b_{1}+a_{1} a_{3} b_{2}\right) \\
c_{3}= & a_{2}{ }^{2} b_{3}+\left(a_{1} a_{5}+a_{2} a_{4}\right) b_{4}+\left(a_{4}^{2}+2 a_{3} a_{5}\right) b_{5} \\
& \quad-\left(2 a_{1} a_{2} b_{1}+\left(a_{1} a_{4}+a_{2} a_{3}\right) b_{2}\right)
\end{aligned}
$$

Titik setimbang endemik $E_{1}=\left(H_{s}{ }^{*}, H_{i}{ }^{*}, S_{S}{ }^{*}, S_{i}{ }^{*}, C^{*}, M^{*}\right)$ eksis jika:

1. $S_{i}<\left(\frac{\left(r_{h}-d_{h}\right)\left(\theta_{i s}+d_{h}\right)}{\left(\frac{\sigma}{d_{c}}\left(d_{h} a_{c}-\left(r_{h}-d_{h}\right) \beta\left(\theta_{i s}+d_{h}\right)\right)\right)}\right)$

2. $R_{0}>1$ 


$$
\begin{gathered}
\frac{d_{s}{ }^{2}\left(\left(\left(r_{h}-d_{h}\right)\left(\theta_{i s}+d_{h}\right)\right)^{2} \frac{\alpha \gamma}{d_{m}} k_{1}+\left(d_{h} a_{c}\right)^{2} \frac{\alpha \gamma}{d_{m}} k_{1}\right)}{2 d_{h} \beta\left(\theta_{i s}+d_{h}\right)\left(\left(r_{h}-d_{h}\right) k_{1} a_{c} \frac{\alpha \gamma}{d_{m}}+r_{h} \beta\left(\theta_{i s}+d_{h}\right) d_{s}{ }^{2}\right)} \\
+\frac{d_{s}{ }^{2}\left(\left(r_{h}-d_{h}\right) r_{h}\left(\beta\left(\theta_{i s}+d_{h}\right)\right)^{2}\right)}{k_{1} d_{h}\left(\left(r_{h}-d_{h}\right) k_{1} a_{c} \frac{\alpha \gamma}{d_{m}}+r_{h} \beta\left(\theta_{i s}+d_{h}\right) d_{s}{ }^{2}\right)} \\
+\frac{d_{s}{ }^{2}\left(r_{h}\left(\beta\left(\theta_{i s}+d_{h}\right)\right)^{2}\right)^{2}}{2 k_{1} a_{c}{ }^{2} d_{h} \beta\left(\theta_{i s}+d_{h}\right) \frac{\alpha \gamma}{d_{m}}\left(\left(r_{h}-d_{h}\right) k_{1} a_{c} \frac{\alpha \gamma}{d_{m}}+r_{h} \beta\left(\theta_{i s}+d_{h}\right) d_{s}{ }^{2}\right)} \\
>1 .
\end{gathered}
$$

\section{$4 \quad$ Analisis Kestabilan Titik Setimbang}

Model matematika penyebaran penyakit schistosomiasis dengan saturated incidence rate pada artikel ini berbentuk sistem diferensial nonlinear sehingga harus dilakukan linearisasi dengan menggunakan matriks Jacobian untuk menguji kestabilan lokal dari titik setimbang yang telah diperoleh sebelumnya. Adapun matriks jacobian dari model adalah sebagai berikut :

$$
J=\left(\begin{array}{cccccc}
q_{1}-\frac{a_{c} C}{1+\beta C}-2 r_{h} \frac{H_{s}}{k_{1}} & \theta_{i s} & 0 & 0 & -\frac{a_{c} H_{s}}{(1+\beta C)^{2}} & 0 \\
\frac{a_{c} C}{1+\beta C} & -q_{2} & 0 & 0 & \frac{a_{c} H_{s}}{(1+\beta C)^{2}} & 0 \\
0 & 0 & q_{3}-\frac{b_{m} M}{1+\gamma M}-2 r_{s} \frac{S_{s}}{k_{2}} & 0 & 0 & -\frac{b_{m} S_{s}}{(1+\gamma M)^{2}} \\
0 & 0 & \frac{b_{m} M}{1+\gamma M} & -d_{s} & 0 & \frac{b_{m} S_{s}}{(1+\gamma M)^{2}} \\
0 & 0 & 0 & \sigma & -d_{c} & 0 \\
0 & \alpha & 0 & 0 & 0 & -d_{m}
\end{array}\right)
$$

dengan

$$
\begin{aligned}
& q_{1}=r_{h}-d_{h} \\
& q_{2}=\theta_{i s}+d_{h} \\
& q_{3}=r_{s}-d_{s}
\end{aligned}
$$

\subsection{Kestabilan Titik Setimbang Non Endemik}

Matriks Jacobian titik setimbang non endemik $E_{0}=\left(H_{s}, H_{i}, S_{S}, S_{i}, C, M\right)=$ $\left(\frac{k_{1}\left(r_{h}-d_{h}\right)}{r_{h}}, 0, \frac{k_{2}\left(r_{s}-d_{s}\right)}{r_{s}}, 0,0,0\right)$ sebagai berikut: 


$$
\begin{aligned}
& \text { dengan } \\
& J\left(E_{0}\right)=\left(\begin{array}{cccccc}
-q_{1} & \theta_{i s} & 0 & 0 & -q_{4} & 0 \\
0 & -q_{2} & 0 & 0 & q_{4} & 0 \\
0 & 0 & -q_{3} & 0 & 0 & -q_{5} \\
0 & 0 & 0 & -d_{s} & 0 & q_{5} \\
0 & 0 & 0 & \sigma & -d_{c} & 0 \\
0 & \alpha & 0 & 0 & 0 & -d_{m}
\end{array}\right) \\
& \begin{array}{l}
q_{1}=r_{h}-d_{h} \\
q_{2}=\theta_{i s}+d_{h} \\
q_{3}=r_{s}-d_{s} \\
q_{4}=\frac{k_{1} a_{c} q_{1}}{r_{h}} \\
q_{5}=\frac{k_{2} b_{m} q_{3}}{r_{s}}
\end{array}
\end{aligned}
$$

Berdasarkan matriks Jacobian tersebut dapat dibentuk persamaan karakteristik dengan menggunakan det $\left(\lambda I-J\left(E_{0}\right)\right)=0$, yaitu

$$
\left(\lambda+q_{1}\right)\left(\lambda+q_{3}\right)\left(\lambda^{4}+p_{1} \lambda^{3}+p_{2} \lambda^{2}+p_{3} \lambda+p_{4}\right)=0
$$

dengan

$$
\begin{aligned}
& p_{1}=q_{2}+d_{m}+d_{s}+d_{c} \\
& p_{2}=d_{c}\left(d_{s}+q_{2}+d_{m}\right)+d_{s}\left(q_{2}+d_{m}\right)+q_{2} d_{m} \\
& p_{3}=d_{c}\left(d_{s}\left(q_{2}+d_{m}\right)+q_{2} d_{m}\right)+q_{2} d_{m} d_{s} \\
& p_{4}=q_{2} d_{m} d_{s} d_{c}-\alpha \sigma q_{4} q_{5}
\end{aligned}
$$

Dari persamaan diatas diperoleh nilai eigen $\lambda_{1}=-q_{1}=-\left(r_{h}-d_{h}\right)$ dan $\lambda_{2}=-q_{2}=$ $-\left(r_{s}-d_{s}\right)$ serta sisanya adalah akar-akar dari persamaan berikut:

$$
\left(\lambda^{4}+p_{1} \lambda^{3}+p_{2} \lambda^{2}+p_{3} \lambda+p_{4}\right)=0
$$

Berdasarkan kriteria Routh-Hurwitz maka titik setimbang non endemik akan stabil jika:
a. $\quad r_{h}>d_{h}$
b. $\quad r_{s}>d_{s}$
c. $\quad R_{0}<1$

\subsection{Kestabilan Titik Setimbang Endemik}

Matriks Jacobian titik setimbang non endemik $E_{1}$ adalah sebagai berikut: 
dengan

$$
J\left(E_{1}\right)=\left(\begin{array}{cccccc}
A_{1} & \theta_{i s} & 0 & 0 & -A_{2} & 0 \\
A_{3} & -q_{2} & 0 & 0 & A_{2} & 0 \\
0 & 0 & A_{4} & 0 & 0 & -A_{5} \\
0 & 0 & A_{6} & -d_{s} & 0 & A_{5} \\
0 & 0 & 0 & \sigma & -d_{c} & 0 \\
0 & \alpha & 0 & 0 & 0 & -d_{m}
\end{array}\right)
$$

$$
\begin{aligned}
& A_{1}=q_{1}-2 \frac{r_{h}}{k_{1}} H_{s}{ }^{*}-\frac{a_{c} C^{*}}{1+\beta C^{*}} \\
& A_{2}=\frac{a_{c} H_{s}{ }^{*}}{\left(1+\beta C^{*}\right)^{2}} \\
& A_{3}=\frac{a_{c} C^{*}}{1+\beta C^{*}} \\
& A_{4}=q_{2}-2 \frac{r_{s}}{k_{2}} S_{s}{ }^{*}-\frac{b_{m} M^{*}}{1+\gamma M^{*}} \\
& A_{5}=\frac{b_{m} S_{s}{ }^{*}}{\left(1+\gamma M^{*}\right)^{2}} \\
& A_{6}=\frac{b_{m} M^{*}}{1+\gamma M^{*}}
\end{aligned}
$$

Berdasarkan matriks Jacobian tersebut dapat dibentuk persamaan karakteristik dengan menggunakan det $\left(\lambda I-J\left(E_{1}\right)\right)=0$, yaitu

$$
\lambda^{6}+m_{1} \lambda^{5}+m_{2} \lambda^{4}+m_{3} \lambda^{3}+m_{4} \lambda^{2}+m_{5} \lambda+m_{6}=0
$$

dengan

$$
\begin{aligned}
& m_{1}=q_{2}+d_{c}+d_{m}+d_{s}-A_{1}-A_{4} \\
m_{2}= & d_{c}\left(d_{s}+d_{m}+q_{2}-A_{1}-A_{4}\right)+d_{s}\left(d_{m}+q_{2}-A_{1}-A_{4}\right)-A_{4}\left(d_{m}+\right. \\
& \left.q_{2}-A_{1}\right)+d_{m}\left(q_{2}-A_{1}\right)-q_{2} A_{1}-\theta_{i s} A_{3} \\
m_{3}= & d_{c}\left(d_{s}\left(d_{m}+q_{2}-A_{1}-A_{4}\right)-A_{4}\left(d_{m}+q_{2}-A_{1}\right)+d_{m}\left(q_{2}-A_{1}\right)-q_{2} A_{1}\right)+ \\
& d_{s}\left(-A_{4}\left(d_{m}+q_{2}-A_{1}\right)+d_{m}\left(q_{2}-A_{1}\right)-q_{2} A_{1}\right)-A_{4}\left(d_{m}\left(q_{2}-A_{1}\right)-q_{2} A_{1}\right)+ \\
& q_{2} A_{1} d_{m}-\theta_{i s} A_{3}\left(d_{c}+d_{s}+d_{m}-A_{4}\right) \\
m_{4}= & d_{c}\left(d_{s}\left(-A_{4}\left(d_{m}+q_{2}-A_{1}\right)+d_{m}\left(q_{2}-A_{1}\right)-q_{2} A_{1}\right)-A_{4}\left(d_{m}\left(q_{2}-A_{1}\right)-\right.\right. \\
& \left.\left.q_{2} A_{1}\right)+q_{2} A_{1} d_{m}\right)-\left(d_{s}\left(A_{4}\left(d_{m}\left(q_{2}-A_{1}\right)-q_{2} A_{1}\right)+q_{2} A_{1} d_{m}\right)-\right. \\
& \left.q_{2} A_{1} d_{m} A_{4}\right)+-\theta_{i s} A_{3}\left(d_{c}\left(d_{s}+d_{m}-A_{4}\right)+d_{s}\left(d_{m}-A_{4}\right)-d_{m} A_{4}\right) \\
m_{5}= & -\left(d_{c}\left(d_{s}\left(A_{4}\left(d_{m}\left(q_{2}-A_{1}\right)-q_{2} A_{1}\right)+q_{2} A_{1} d_{m}\right)-q_{2} A_{1} d_{m} A_{4}\right)-\right. \\
& \left.q_{2} A_{1} d_{m} A_{4} d_{s}\right)+-\theta_{i s} A_{3}\left(d_{c}\left(d_{s}\left(d_{m}-A_{4}\right)-d_{m} A_{4}\right)-d_{m} A_{4} d_{s}\right) \\
m_{6} & =q_{2} A_{1} d_{m} A_{4} d_{s} d_{c}-\theta_{i s} A_{3}\left(d_{m} A_{4} d_{s} d_{c}+-A_{4} A_{3} \alpha \sigma A_{2} \lambda-A_{4} A_{3} \alpha \sigma A_{2} d_{s}+\right. \\
& \left.\alpha \sigma A_{2} A_{3} A_{4} A_{5}\right)
\end{aligned}
$$

Untuk menentukan akar-akar dari persamaan karakteristik diatas sulit untuk dicari solusinya secara analitik, sehingga titik setimbang penyebaran penyakit schistosomiasis ini akan di analisis melalui simulasi numerik dengan menggunakan grafik bidang fase. Berikut adalah tabel nilai awal dan nilai parameter yang digunakan. 
Tabel 3 Nilai Parameter untuk Menentukan Kestabilan Titik Setimbang Endemik

\begin{tabular}{|c|c|c|}
\hline Parameter & Nilai & Sumber \\
\hline$r_{h}$ & 0,005 & Asumsi \\
\hline$k_{1}$ & 3000 & Asumsi \\
\hline$a_{c}$ & 0,00001914 & {$[7]$} \\
\hline$\theta_{i s}$ & 0,00075 & {$[7]$} \\
\hline$d_{h}$ & 0,00003914 & {$[7]$} \\
\hline$\beta$ & 0,004 & Asumsi \\
\hline$r_{s}$ & 0,02 & Asumsi \\
\hline$k_{2}$ & 2000 & Asumsi \\
\hline$b_{m}$ & 0,000084 & {$[7]$} \\
\hline$d_{s}$ & 0,00033 & {$[7]$} \\
\hline$\gamma$ & 0,003 & Asumsi \\
\hline$\sigma$ & 0,7 & {$[7]$} \\
\hline$d_{c}$ & 1 & {$[7]$} \\
\hline$\alpha$ & 0,6 & {$[7]$} \\
\hline$d_{m}$ & 2 & {$[7]$} \\
\hline
\end{tabular}

Nilai awal untuk populasi disajikan pada Tabel 4 berikut ini.

Tabel 4 Nilai Awal untuk Bidang Fase Model Penyebaran Penyakit Schistosomiasis dengan Saturated Incidence Rate

\begin{tabular}{|c|c|c|c|c|c|c|}
\hline Nilai Awal & $H_{S}{ }^{*}(0)$ & $H_{i}{ }^{*}(0)$ & $S_{S}{ }^{*}(0)$ & $S_{i}{ }^{*}(0)$ & $C^{*}(0)$ & $M^{*}(0)$ \\
\hline 1 & 2900 & 1200 & 1000 & 1000 & 3000 & 3000 \\
\hline 2 & 1800 & 1700 & 900 & 800 & 3500 & 2500 \\
\hline 3 & 2200 & 1300 & 800 & 600 & 2000 & 1500 \\
\hline
\end{tabular}

Berdasarkan nilai parameter di atas dan pemberian tiga nilai awal yang berbeda dengan rentang waktu $t=0$ hingga $t=1000$, diperoleh grafik sebagai berikut:

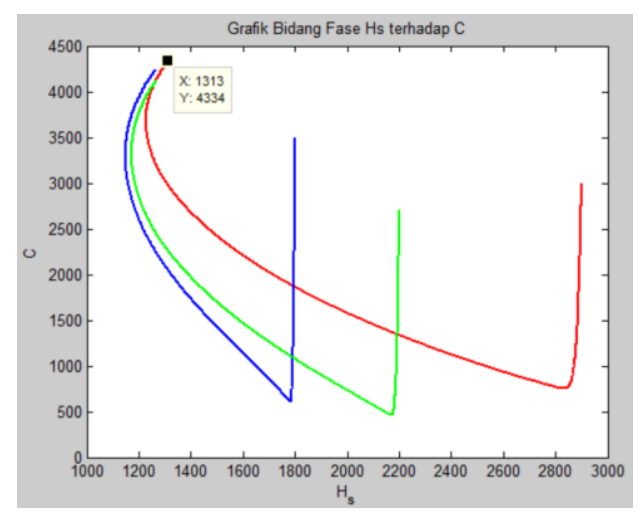

Gambar 1 Grafik Bidang Fase Populasi $H_{s}$ terhadap $H_{i}$ pada Model Matematika Penyebaran Penyakit Schistosomiasis dengan Saturated Incidence Rate 
Gambar 1 merupakan grafik bidang fase populasi $H_{S}$ terhadap $C$ dari model penyebaran penyakit schistosomiasis dengan saturated incidence rate. Gambar di atas menunjukkan bahwa pemberian nilai tiga awal yang berbeda akan menghasilkan grafik yang cenderung konvergen ke satu titik. Titik tersebut yaitu $(1313 ; 4334)$ yang tidak lain adalah bagian dari titik setimbang penyebaran penyakit schistosomiasis dengan saturated incidence rate. Selain itu berdasarkan pada nilai parameter yang diberikan maka didapatkan nilai $R_{0}=9.334074751>1$.

Dari uraian diatas, dapat disimpulkan bahwa titik setimbang $E_{1}=$ $\left(H_{s}{ }^{*}, H_{i}{ }^{*}, S_{s}{ }^{*}, S_{i}{ }^{*}, C^{*}, M^{*}\right)$ pada model matematika penyebaran penyakit schistosomiasis dengan saturated incidence rate stabil asimtotis jika dan hanya jika $R_{0}>1$. Hal ini menunjukkan bahwa populasi cercaria $(C)$ dan miracidia $(M)$ dapat menularkan schistosomiasis kepada kurang lebih dari satu penderita baru, sehingga schistosomiasis dapat menyebar luas atau dengan kata lain terjadi kondisi endemik schistosomiasis.

\subsection{Analisis Sensitivitas Parameter}

Analisis sensitivitas digunakan untuk mengetahui parameter yang paling berpengaruh pada suatu model (Chitniz dkk, 2009). Dalam hal ini akan ditentukan indeks sensitivitas pada setiap parameter yang terlibat pada basic reproduction number $\left(R_{0}\right)$ dari model matematika penyebaran penyakit schistosomiasis dengan saturated incidence rate.Nilai $R_{0}$ yang akan digunakan dalam analisis sensitivitas model matematika penyebaran penyakit schistosomiasis dengan saturated incidence rate adalah

$$
R_{0}=\sqrt[4]{\frac{\alpha}{\left(\theta_{i s}+d_{h}\right)}\left(\frac{\sigma}{d_{s}}\right)\left(\frac{a_{c} k_{1}\left(r_{h}-d_{h}\right)}{r_{h} d_{c}}\right)\left(\frac{b_{m} k_{2}\left(r_{s}-d_{s}\right)}{r_{s} d_{m}}\right)}
$$

Indeks sensitivitas parameter dirumuskan sebagai berikut:

dengan:

$$
i d m=\frac{\partial R_{0}}{\partial p} \times \frac{p}{R_{0}}
$$

$i d m=$ indeks sensitivitas parameter $p$

$p=$ parameter yang dianalisis

Terlihat bahwa terdapat 13 parameter yang akan dihitung indeks sensitivitasnya yaitu $r_{h}, k_{1}, a_{c}, \theta_{i s}, d_{h}, r_{s}, k_{2}, b_{m}, d_{s}, \sigma, d_{c}, \alpha, d_{m}$. Hasil indeks sensitivitas parameter model matematika penyebaran penyakit schistosomiasos dengan saturated incidence rate dapat dilihat pada Tabel 5 berikut ini: 
Tabel 5 Hasil Perhitungan Indeks Parameter Model Matematika Penyebaran Penyakit Schistosomiasis dengan Saturated Incidence Rate

\begin{tabular}{|c|c|}
\hline Parameter & Indeks Sensitivitas \\
\hline$r_{h}$ & 0,0019 \\
\hline$k_{1}$ & 0,25 \\
\hline$a_{c}$ & 0,25 \\
\hline$\theta_{i s}$ & $-0,237$ \\
\hline$d_{h}$ & $-0,014$ \\
\hline$r_{s}$ & 0.0042 \\
\hline$k_{2}$ & 0,25 \\
\hline$b_{m}$ & 0,25 \\
\hline$d_{s}$ & -0.254 \\
\hline$\sigma$ & 0,25 \\
\hline$d_{c}$ & $-0,25$ \\
\hline$\alpha$ & 0,25 \\
\hline$d_{m}$ & $-0,25$ \\
\hline
\end{tabular}

Berdasarkan Tabel 5 dapat diperoleh beberapa hal yaitu:

1. Indeks sensitivitas parameter $r_{h}$ adalah 0,0019 , artinya jika laju kelahiran pada populasi manusia bertambah (berkurang) sebesar $10 \%$, maka nilai $R_{0}$ akan bertambah (berkurang) sebesar $0.019 \%$.

2. Indeks sensitivitas parameter $k_{1}$ adalah 0,25 , artinya jika jumlah kapasitas pendukung populasi manusia bertambah (berkurang) sebesar $10 \%$, maka nilai $R_{0}$ akan bertambah (berkurang) sebesar 2,5\%.

3. Indeks sensitivitas parameter $a_{c}$ adalah 0,25 , artinya jika laju transmisi cercaria terhadap manusia bertambah (berkurang) sebesar $10 \%$, maka nilai $R_{0}$ akan berkurang (bertambah) sebesar 2,5\%.

4. Indeks sensitivitas parameter $\theta_{i s}$ adalah $-0,237$, artinya jika laju transmisi manusia terinfeksi ke manusia rentan bertambah (berkurang) sebesar $10 \%$, maka nilai $R_{0}$ akan berkurang (bertambah) sebesar $2,37 \%$.

5. Indeks sensitivitas parameter $d_{h}$ adalah $-0,014$, artinya jika laju kematian alami populasi manusia bertambah (berkurang) sebesar $10 \%$, maka nilai $R_{0}$ akan berkurang (bertambah) sebesar 0,14\%.

6. Indeks sensitivitas parameter $r_{s}$ adalah 0,0042 artinya jika laju kelahiran pada populasi siput bertambah (berkurang) sebesar $10 \%$, maka nilai $R_{0}$ akan bertambah (berkurang) sebesar $0,042 \%$.

7. Indeks sensitivitas parameter $k_{2}$ adalah 0,25 , artinya jika kapasitas pendukung populasi siput bertambah (berkurang) sebesar $10 \%$, maka nilai $R_{0}$ akan bertambah (berkurang) sebesar 2,5\%.

8. Indeks sensitivitas parameter $b_{m}$ adalah 0,25 , artinya jika laju transmisi miracidia terhadap siput bertambah (berkurang) sebesar $10 \%$, maka nilai $R_{0}$ akan bertambah (berkurang) sebesar 2,5\%. 
9. Indeks sensitivitas parameter $d_{s}$ adalah $-0,254$, artinya jika laju kematian alami populasi siput bertambah (berkurang) sebesar $10 \%$, maka nilai $R_{0}$ akan berkurang (bertambah) sebesar 2,54\%.

10. Indeks sensitivitas parameter $\sigma$ adalah 0,25 , artinya jika laju produksi cercaria per siput yang terinfeksi bertambah (berkurang) sebesar $10 \%$, maka nilai $R_{0}$ akan bertambah (berkurang) sebesar 2,5\%.

11. Indeks sensitivitas parameter $d_{c}$ adalah $-0,25$, artinya jika laju kematian alami cercaria bertambah (berkurang) sebesar $10 \%$, maka nilai $R_{0}$ akan berkurang (bertambah) sebesar 2,5\%.

12. Indeks sensitivitas parameter $\alpha$ adalah 0,25 , artinya jika laju penetasan miracidia dari telur bertambah (berkurang) sebesar $10 \%$, maka nilai $R_{0}$ akan bertambah (berkurang) sebesar $2,5 \%$.

13. Indeks sensitivitas parameter $d_{m}$ adalah $-0,25$, artinya jika laju penetasan miracidia dari telur bertambah (berkurang) sebesar 10\%, maka nilai $R_{0}$ akan berkurang (bertambah) sebesar 2,5\%.

Berdasarkan penjelasan diatas, terdapat 13 parameter yang mempengaruhi besar kecilnya nilai $R_{0}$. Sedangkan parameter yang paling berpengaruh dalam model matematika penyebaran schistosomiasis dengan saturated incidence rate adalah $d_{s}$. Hal itu karena nilai indeks parameter $d_{s}$ memiliki nilai mutlak indeks parameter tertinggi dibanding dengan parameter lainnya.

Selanjutnya akan disimulasikan parameter $d_{s}$ dan $r_{s}$ terhadap $R_{0}$. Pada simulasi ini dipilih nilai $d_{s}=0,2, d_{s}=0,5$ dan $d_{s}=0,7$. Hasil simulasi sensitivitas parameter $d_{s}$ terhadap $R_{0}$ adalah sebagai berikut:

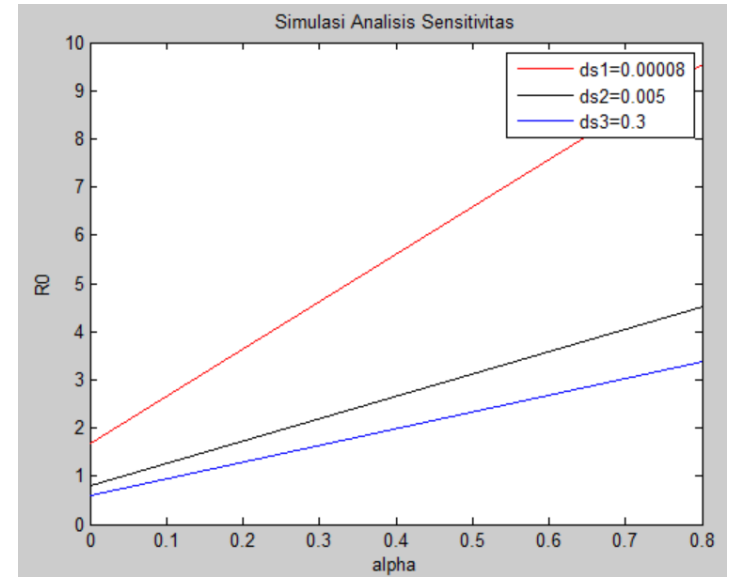

Gambar 2 Grafik Sensitivitas $d_{s}$ dan $\alpha$ terhadap $R_{0}$ 
Berdasarkan Gambar 2 menujukkan bahwa dengan memilih tiga nilai $d_{s}$ yang berbeda dan nilai $r_{s}$, grafik menujukkan bahwa semakin kecil nilai $d_{s}$ dan $\alpha$ mengakibatkan semakin besar nilai $R_{0}$.

\section{Simulasi Numerik dan Interpretasi Model Matematika Penyebaran Penyakit Schistosomiasis dengan Saturated Incidence Rate}

Subbab ini membahas mengenai simulasi numerik model matematika penyebaran penyakit schistosomiasis dengan saturated incidence rate. Terdapat dua kondisi yang disimulasikan, yaitu saat kondisi bebas penyebaran penyakit schistosomiasis dan kondisi penyebaran penyakit schistosomiasis. Simulasi dilakukan dengan bantuan software MATLAB dan dengan memasukkan nilai awal untuk masing-masing populasi.

Kondisi bebas Penyakit Schistosomiasis terjadi ketika popluasi penyebar schistosomiasis tidak ada atau dengan kata lain tidak ada penyebaran penyakit schistosomiasis $(R 0<1)$. Simulasi dilakukan untuk $t=0$ sampai $t=100$ dalam satuan hari. Nilai parameter saat kondisi bebas penyebaran schistosomiasis adalah sebagai berikut:

Tabel 6 Nilai Parameter untuk Menentukan Kestabilan Titik Setimbang Non Endemik

\begin{tabular}{|c|c|c|}
\hline Parameter & Nilai & Sumber \\
\hline$r_{h}$ & 0,005 & Asumsi \\
\hline$k_{1}$ & 1600 & Asumsi \\
\hline$a_{c h}$ & 0,0001914 & {$[7]$} \\
\hline$\theta_{i s}$ & 0,075 & {$[7]$} \\
\hline$d_{h}$ & 0,00003914 & {$[7]$} \\
\hline$\beta$ & 0,03 & Asumsi \\
\hline$r_{s}$ & 0,09 & Asumsi \\
\hline$k_{2}$ & 1000 & Asumsi \\
\hline$b_{m s}$ & 0,0000084 & {$[7]$} \\
\hline$d_{s}$ & 0,033 & {$[7]$} \\
\hline$\gamma$ & 0,04 & Asumsi \\
\hline$\sigma$ & 0,0007 & {$[7]$} \\
\hline$b$ & 1 & {$[7]$} \\
\hline$d_{c}$ & 0,035 & {$[7]$} \\
\hline$\alpha$ & 2 & {$[7]$} \\
\hline
\end{tabular}

Berdasarkan nilai parameter yang diberikan pada Tabel 6, diperoleh $R_{0}=0,053176984<$ 1. Berikut merupakan hasil simulasi numerik saat kondisi bebas penyebaran penyakit schistosomiasis: 


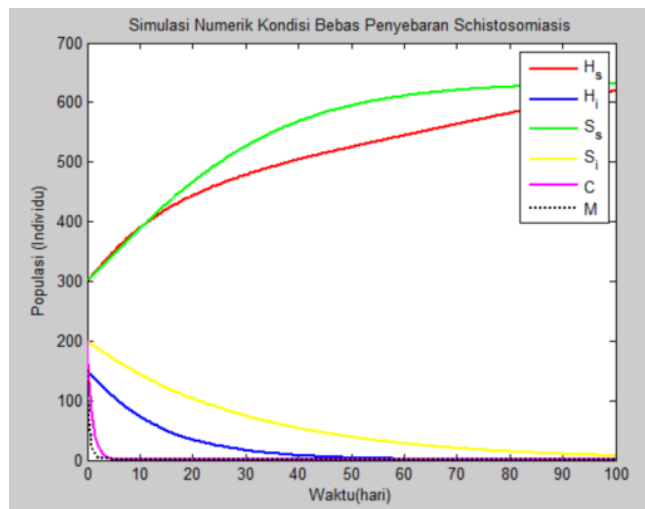

Gambar 3 Grafik Simulasi Numerik saat Kondisi Bebas Penyebaran Penyakit Schistosomiasis

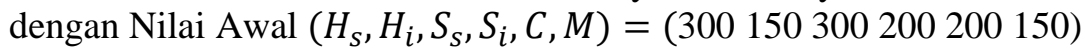

Gambar 4 merupakan hasil simulasi pada saat kondisi bebas penyebaran penyakit schistosomiasis dengan saturated incidence rate. Jumlah populasi manusia rentan $H_{S}$ dan populasi siput $S_{S}$ rentan cenderung naik karena tidak adanya penyebaran penyakit schistosomiasis. sementara, Jumlah populasi manusia terifeksi $\left(H_{i}\right)$, jumlah populasi siput terinfeksi $\left(S_{i}\right)$, jumlah kepadatan cercaria $(C)$ serta jumlah kepadatan miracidia $(M)$ pada kondisi bebas penyebaran schistosomiasis akan cenderung turun hingga akhirnya mengalami kepunahan.

Kondisi penyebaran penyakit schistosomiasis terjadi ketika terdapat populasi penyebar schistosomiasis atau dengan kata lain ada penyebaran schistosomiasis $\left(R_{0}>1\right)$. Simulasi dilakukan untuk $t=0$ sampai $t=1000$ dalam satuan hari. Nilai parameter saat kondisi penyebaran penyakit schistosomiasis dengan saturated incidence rate sebagai berikut:

Tabel 7 Nilai Parameter untuk Menentukan Kestabilan Titik Setimbang Endemik

\begin{tabular}{|c|c|c|}
\hline Parameter & Nilai & Sumber \\
\hline$r_{h}$ & 0,005 & Asumsi \\
\hline$k_{1}$ & 3000 & Asumsi \\
\hline$a_{c}$ & 0,00001914 & {$[7]$} \\
\hline$\theta_{i s}$ & 0,00075 & {$[7]$} \\
\hline$d_{h}$ & 0,00003914 & {$[7]$} \\
\hline$\beta$ & 0,004 & Asumsi \\
\hline$r_{s}$ & 0,02 & Asumsi \\
\hline$k_{2}$ & 2000 & Asumsi \\
\hline$b_{m}$ & 0,000084 & {$[7]$} \\
\hline$d_{s}$ & 0,00033 & {$[7]$} \\
\hline$\gamma$ & 0,003 & Asumsi \\
\hline$\sigma$ & 0,7 & {$[7]$} \\
\hline$d_{c}$ & 1 & {$[7]$} \\
\hline$\alpha$ & 0,6 & {$[7]$} \\
\hline$d_{m}$ & 2 & {$[7]$} \\
\hline
\end{tabular}


Berdasarkan nilai parameter yang diberikan pada Tabel 7 , diperoleh $R_{0}=$ $9,334074751>1$. Berikut merupakan hasil simulasi numerik saat kondisi penyebaran penyakit schistosomiasis dengan saturated incidence rate:

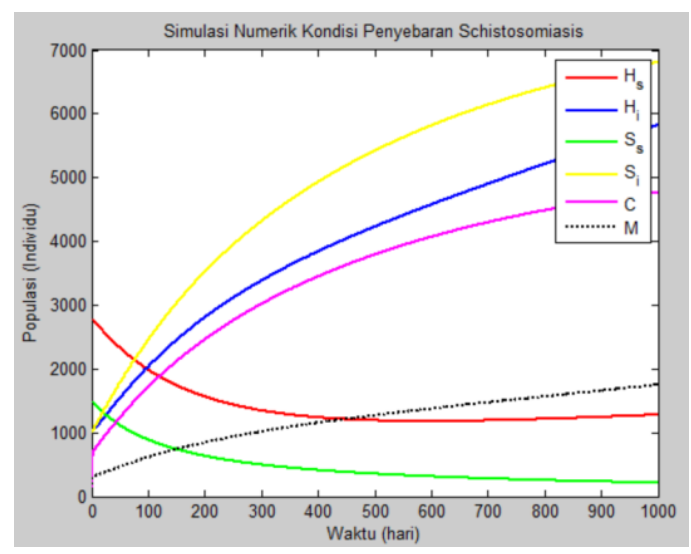

Gambar 4 Grafik Simulasi Numerik saat Kondisi Penyebaran Penyakit Schistosomiasis dengan Nilai Awal $\left(H_{S}, H_{i}, S_{S}, S_{i}, C, M\right)=(2800100015001000100100)$.

Gambar 4 merupakan hasil simulasi pada populasi manusia saat kondisi penyebaran penyakit schistosomiasis dengan saturated incidence rate. Jumlah populasi manusia terifeksi $H_{i}$ jumlah populasi siput terinfeksi $S_{i}$, jumlah kepadatan cercaria $(C)$ serta jumlah kepadatan miracidia $(M)$ pada kondisi penyebaran schistosomiasis akan cenderung naik sebelum akhirnya berada pada keadaan konstan.

\section{Kesimpulan}

Berdasarkan pembahasan yang telah diuraikan sebelumnya, maka dapat ditarik kesimpulan sebagai berikut:

1. Model matematika penyebaran penyakit schistosomiasis dengan saturated incidence rate memiliki dua titik setimbang yaitu titik setimbang non endemik $\left(E_{0}\right)$ dan titik setimbang endemik $\left(E_{1}\right)$. Titik setimbang non endemik akan stabil asimtotis jika $r_{h}>d_{h}, r_{s}>d_{s}$ dan $R_{0}<1$. Titik setimbang endemik $\left(E_{1}\right)$ cenderung stabil asimtotis jika $R_{0}>1$, dengan

$$
R_{0}=\sqrt[4]{\frac{\alpha}{\left(\theta_{i s}+d_{h}\right)}\left(\frac{\sigma}{d_{s}}\right)\left(\frac{a_{c} k_{1}\left(r_{h}-d_{h}\right)}{r_{h} d_{c}}\right)\left(\frac{b_{m} k_{2}\left(r_{s}-d_{s}\right)}{r_{s} d_{m}}\right)}
$$

2. Berdasarkan hasil simulasi numerik yang telah dilakukan, dapat disimpulkan bahwa jumlah populasi manusia terifeksi $\left(H_{S}\right)$, jumlah populasi siput terinfeksi $\left(H_{i}\right)$, jumlah kepadatan cercaria $(C)$ serta jumlah kepadatan miracidia $(M)$ pada kondisi bebas penyebaran schistosomiasis akan cenderung turun hingga akhirnya punah. Lain halnya pada kondisi penyebaran schistosomiasis, jumlah keempat populasi tersebut cenderung naik sebelum akhirnya berada pada keadaan konstan. 


\section{$7 \quad$ Daftar Pustaka}

[1] World Health Organization (WHO), 2019, Schistosomiasis, https://www.who.int/newsroom/fact-sheets/detail/schistosomiasis, 24 November 2019.

[2] Zhang, S., Wang, T., Zhou, Y., Chao, Z., dan Wang, N., 2019, Influence of the Three Gorges Dam on schistosomiasis control in the middle and lower reaches of the Yangtze River, Global Health Journal, 3:1-7.

[3] Departemen Kesehatan Republik Indonesia (Depkes RI), 2016, Schistosomiasis Masih Ada, Butuh Peran Lintas Sektor Bebaskan Indonesia https://www.depkes.go.id/article/print/16102600002/schistosomiasis-masih-ada-butuhperan-lintas-sektor-bebaskan-indonesia.html, 17 November 2019.

[4] World Health Organization (WHO), 2018, Schistosomiasis, https://www.who.int/newsroom/facts-in-pictures/detail/10-facts-on-schistosomiasis, 15 November 2019.

[5] Xiang, J., Chen, H., dan Ishikawa, H., 2013, A mathematical model for the transmission of Schistosoma japonicum in consideration of seasonal water level fluctuations of Poyang Lake in Jiangxi, China, Parasitology International, 62:118-126.

[6] Ding, C., Tao, N., Sun, Y., dan Zhu, Y, 2016, The effect of time delays on transmission dynamics of schistosomiasis, Chaos, Solitons and Fractals,91:360-371.

[7] Ding, C., Liu, W., Sun, Y., dan Zhu, Y, 2019, A delayed Schistosomiasis transmission model and its dynamics, Chaos, Solitons and Fractals, 118, 18-34. 